\title{
Migration patterns in Norwegian spring-spawning herring: why young fish swim away from the wintering area in late summer
}

\author{
Cecilie Kvamme $^{1,2, *}$, Leif Nøttestad ${ }^{1}$, Anders Fernö ${ }^{1,2}$, Ole Arve Misund ${ }^{1}$, \\ Are Dommasnes ${ }^{1}$, Bjørn Erik Axelsen ${ }^{1}$, Padmini Dalpadado ${ }^{1}$, Webjørn Melle ${ }^{1}$ \\ ${ }^{1}$ Institute of Marine Research, PO Box 1870 Nordnes, 5817 Bergen, Norway \\ ${ }^{2}$ Department of Fisheries and Marine Biology, University of Bergen, PO Box 7800, 5020 Bergen, Norway
}

\begin{abstract}
Norwegian spring-spawning herring Clupea harengus make extensive feeding migrations in the Norwegian Sea during summer. At the end of the feeding season herring may meet conflicting demands between moving to areas with uncertain food abundance and predation risk and migrating to the wintering area at the coast. Previous studies on the distribution of herring indicate a general eastward migration in late summer, but do not reveal actual migration patterns and orientation mechanisms. About 700 schools of herring were tracked using multi-beam sonar during 2 surveys in the Norwegian Sea in July 1995 and 1996. In coastal areas off Northern Norway, migrating schools of young herring ( 2 to 6 yr) swam contrary to expectations westward with a mean migration speed of $0.65 \mathrm{~m} \mathrm{~s}^{-1}$. MOCNESS samples of zooplankton biomass, herring stomach samples and condition factors indicated better feeding conditions westward off the continental slope than in coastal areas, strongly suggesting that young herring migrated westward to improve feeding conditions. This migration could be released by low food abundance and be based on a large-scale genetic predictive orientation mechanism. West of the continental shelf and slope, in waters with elevated abundance of larger prey items, migration directions were variable. Schools of young herring reaching higher food supply seemed to stop their westward migration and stay in these waters to feed. A small number of older herring (>Age 6) were located even farther west near the Arctic Front where food concentrations were greatest. Predictive orientation mechanisms toward richer feeding areas may improve with age as a result of experience and learning.
\end{abstract}

KEY WORDS: Herring $\cdot$ Migration $\cdot$ Sonar $\cdot$ Orientation mechanisms $\cdot$ Feeding $\cdot$ Swimming speed and direction

\section{INTRODUCTION}

The migration pattern of Norwegian spring-spawning herring Clupea harengus has varied during the past century (Dragesund et al. 1980, 1997, Røttingen 1992) (Fig. 1) in connection with changes in environmental factors and herring stock size (Jakobsson 1969, Dragesund et al. 1980, 1997). During the past decade the migration pattern has been relatively constant (Dragesund et al. 1997). Juvenile herring stay in the

*Email: cecilie.kvamme@imr.no
Barents Sea the first 2 to 4 yr (Dragesund et al. 1980, 1997). Young herring ( $\leq 6 \mathrm{yr}$ ) mainly feed within coastal areas of Western Norway, whereas older herring (>6 yr) make a large-scale feeding migration into the Norwegian Sea (Anonymous 1995, 1996b, Dragesund et al. 1997). The older herring have a similar migration pattern to that recorded between 1950 and 1962 (Fig. 1a), except for a change in wintering area from northeast of Iceland to Vestfjorden, northern Norway (Dragesund et al. 1997) (Figs. 1d \& 2). 
a)

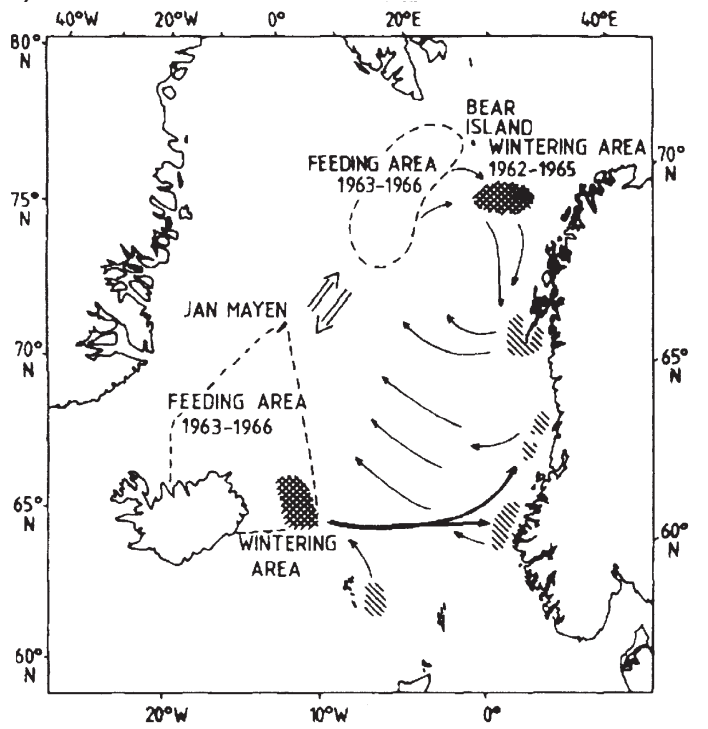

c)

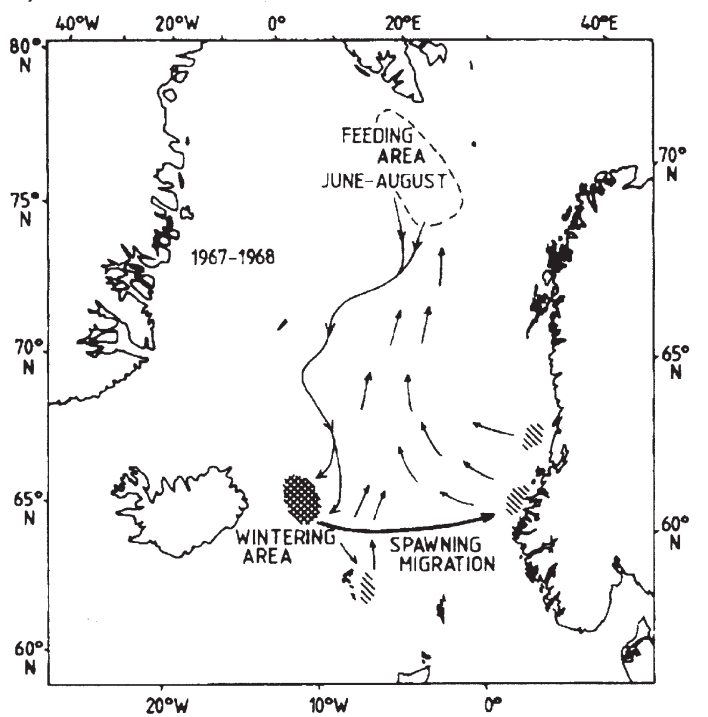

b)

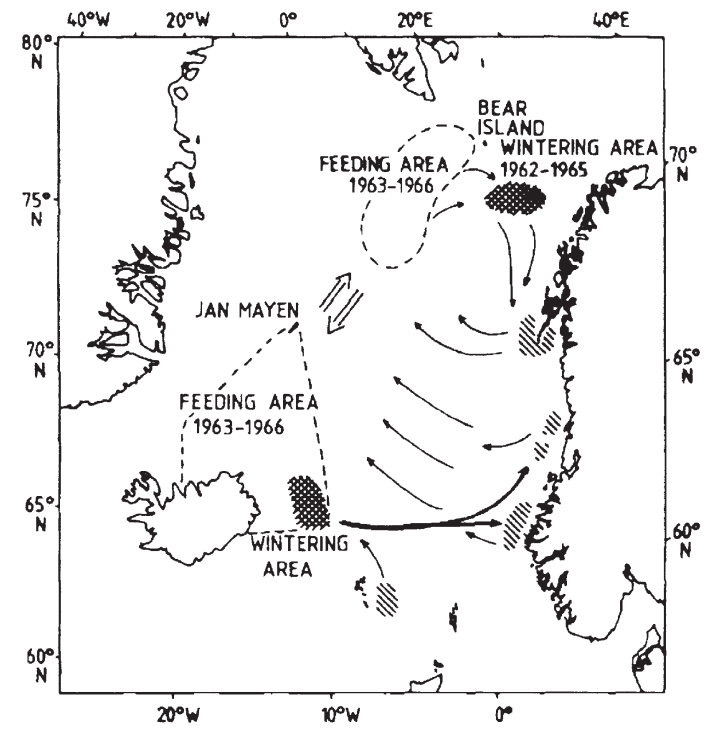

d)

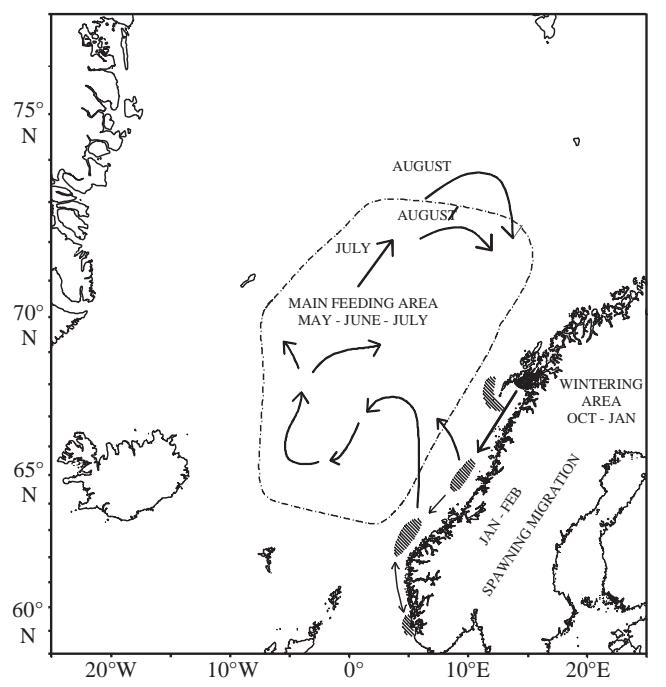

Fig. 1. Clupea harengus. Variations in the migration pattern of Norwegian spring-spawning herring. (a) 1950 to 1962 . Spawning areas in 1950 to 1959 are shown in the upper right corner. (b) 1963 to 1966. Double arrows indicate a separation of the herring stock in 2 separate areas. (c) 1967 to 1968. The 2 components rejoined and adopted a combined migration pattern. (d) General migration pattern of adult herring during the last decade

The main migration pattern of Norwegian springspawning herring has been studied by tagging experiments (Fridriksson \& Aasen 1950, Røttingen \& Røttingen 1991) and acoustic observations of distribution during different periods of the year (i.e. Anonymous 1995, 1996b, Misund et al. 1998). Using large-scale distribution studies to interpret migration patterns may, however, result in misleading conclusions, and there have been few studies of the actual migration pattern of individual herring schools (but see Hafsteinsson \& Misund 1995, Misund et al. 1997).
Herring may use predictive (genetic factors or learning) and reactive (response to near field or state-space comparisons) orientation mechanisms during migration (Harden Jones 1968, Corten 1993, Fernö et al. 1998). Predictive orientation mechanisms involve orientation towards areas with expected higher habitat quality without the use of information from the near field. A combination of reactive and predictive orientation mechanisms may provide herring with a flexible migration strategy, adapted to both predictable and unpredictable conditions (Fernö et al. 1998). 
After spawning at the coast, adult herring start their feeding period by migrating into the Norwegian Sea (Misund et al. 1997) in large schools with high swimming speed and stable swimming direction (Nøttestad et al. 1996). The westward migration is probably driven by predictive mechanisms involving both genetic factors and learning (Fernö et al. 1998). During their feeding period herring mainly follow the seasonal production cycles of zooplankton, with the migration adapted to the food distribution (Pavshtiks 1959, Østvedt 1965, Melle et al. 1994). Herring delayed their westward feeding migration in the spring of 1998 when the food resources in the eastern part of the Norwegian Sea were unusually abundant (Holst et al. 1998), illustrating the importance of food shortage in triggering the westward migration. Food availability should thus largely determine the spatial distribution of herring during the feeding season (Pavshtiks 1959, Østvedt 1965, Melle et al. 1994, Jakobsson \& Østvedt 1996, Dragesund et al. 1997).

The time for termination of feeding and migration towards the wintering areas varies. Røttingen (1988) observed that herring entered the wintering areas in September, but feeding herring schools have also been observed at that time (Pavshtiks 1959, Misund 1993). The herring hardly feed during wintering and spawning (Nøttestad et al. 1996, Slotte 1999), and the energy-demanding overwintering period and subsequent spawning migration (Slotte 1999) requires an accumulation of energy reserves during the feeding period. From an energetic point of view the herring should be expected to continue feeding for as long as possible before overwintering. Our study concentrated on late summer as the period when herring make decisions on where and when the overwintering will take place. We combined detailed smallscale school tracking observations with existing large-scale distribution data on herring and their prey to improve the understanding of herring migrations. Based on interpretations of migration patterns from previous studies of the stock distribution throughout the year (Røttingen 1992, Dragesund et al. 1997), older herring were expected to have an easterly migration pattern towards Lofoten in late summer, whereas young herring were expected to remain within coastal areas, swimming towards their wintering area.

\section{MATERIALS AND METHODS}

A total of 695 schools of Norwegian spring-spawning herring were tracked during 2 surveys in the Norwegian Sea, from 7 July to 2 August 1995 and from 9 to 19 July 1996 (Figs. 2 \& 3). The RV 'Johan Hjort' followed a predetermined survey track at standard survey speed ( 10 knots). Schools at 50 to $400 \mathrm{~m}$ distance from the vessel were recorded using a Simrad SR $24024 \mathrm{kHz}$ multi-beam sonar (Johannessen 1992) with a ping rate depending on range ( 2 to 10 pings $\mathrm{s}^{-1}$ ). The built in school tracking feature of the sonar provided information about school swimming speed, relative bearing to the ship, vessel to school distance, centre depth and horizontal area (Table 1). School swimming speed was measured as the movement of the school's acoustic centre of gravity in relation to the earth's surface,

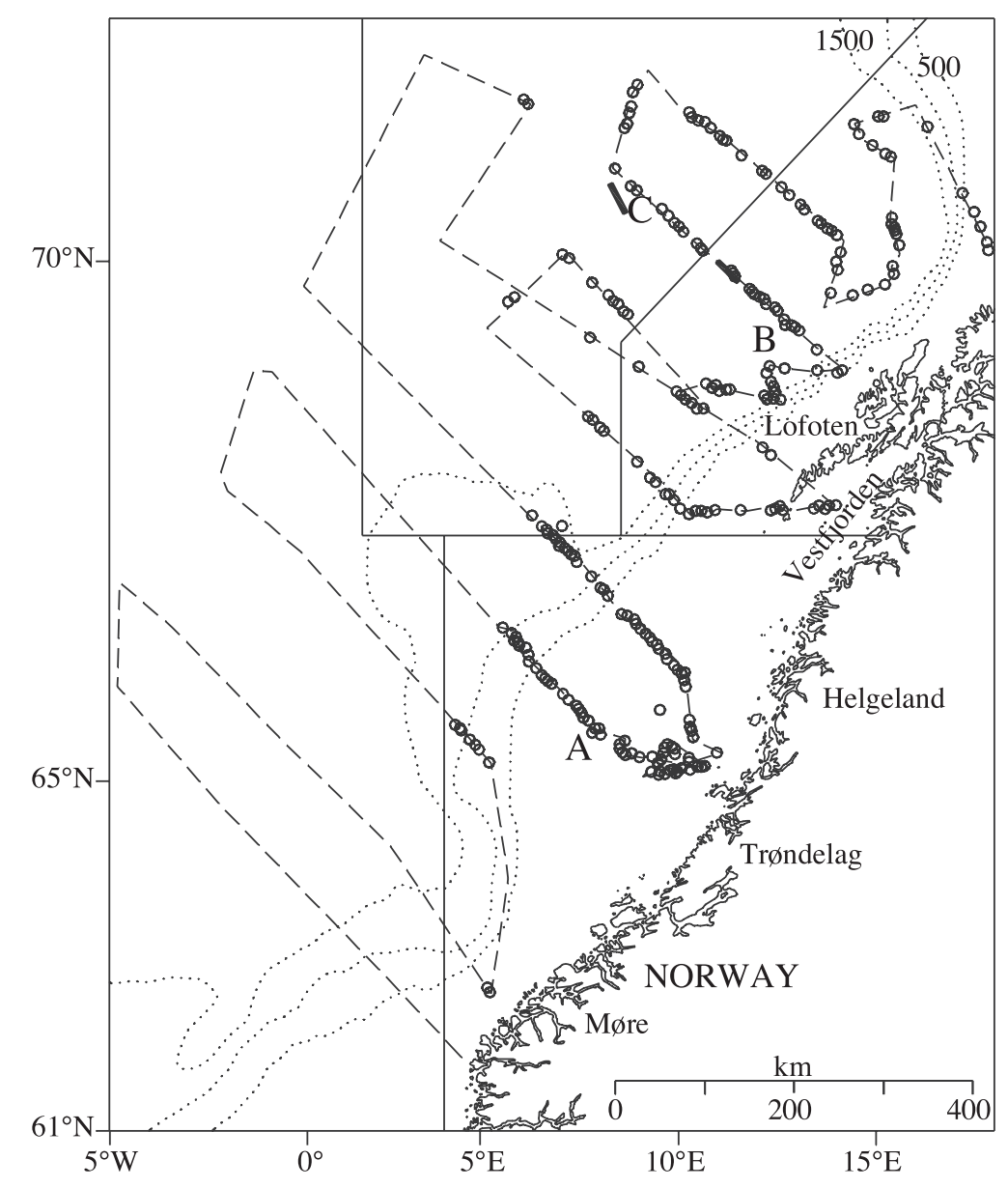

Fig. 2. The sub-areas, based on linear distance to the main wintering area of Norwegian spring-spawning herring Clupea harengus in Vestfjorden, habitat (continental shelf, continental slope and open ocean), and age of herring in trawl catches ( $\leq 6 \mathrm{yr},>6 \mathrm{yr}$ ). Survey track of RV 'Johan Hjort' 7 July to 2 August 1995 (- - -), depth (m) and each school observation from the 1995 survey (O) are indicated. The 2 thick lines show where the 2 subsets $(n \sim 100)$ from the 1996 survey (RV 'Johan Hjort' 9 to 19 July, see Fig. 3) were taken 


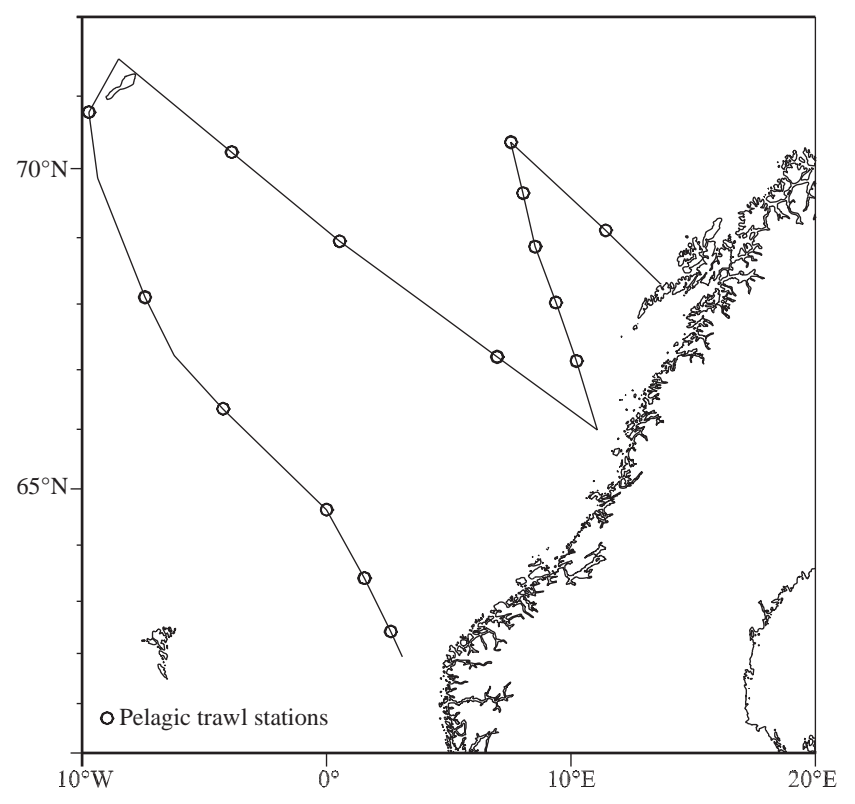

Fig. 3. Survey track and pelagic trawl stations, RV 'Johan Hjort', 9 to 19 July 1996

which gives an estimate of the horizontal distance covered by a school per unit time. The horizontal beam width of the sonar was $90^{\circ}$. The sonar beam was oriented $45^{\circ}$ to the port or starboard side of the vessel. A tilt angle of 5 to $10^{\circ}$ and a Time Varied Gain (TVG) of $20 \log \mathrm{R}$ were applied throughout both surveys. The geographical position of the vessel was recorded from the ship-borne GPS at the beginning of each acoustic registration. A $38 \mathrm{kHz}$ Simrad EK 500 echo sounder in combination with the Bergen Echo Integrator (BEI) (Knudsen 1990) was operated continuously throughout the surveys.

Each detected school was classified as herring, blue whiting Micromesistius poutassou or mackerel Scomber scombrus based mainly on visual scrutiny of the echo traces in addition to pelagic trawl samples (96 in 1995 [Anonymous 1996a] and 15 in 1996 [Fig. 3]) conducted in the area. The trawl catches were not necessarily from the detected schools, but herring dominated the observations. Length, weight and age (fishscales) of individual herring were measured, and the condition factor calculated as $k=w \times l^{-3}$, where $w$ is the weight in grams and $l$ is the length in centimetres. Stomach samples were collected from the trawl catches in 1995 and indices of stomach fullness recorded. MOCNESS was used for plankton sampling, mostly down to $700 \mathrm{~m}$ or to the bottom. Sampling and dry weight estimation of biomass were performed as described by Dalpadado et al. (2000). Prior to drying, the samples were sieved through 2000, 1000 and $180 \mu \mathrm{m}$ sieves to get size fractioned biomass estimates. From the $2000 \mu \mathrm{m}$ fraction all krill, shrimps and fish were removed and weighed separately. The plankton dry weight samples from the upper $200 \mathrm{~m}$ were depth integrated to $g$ dry weight $\mathrm{m}^{-2}$ surface and provided a measure of the food supply of herring.

The survey area was retrospectively split into 3 subareas (Fig. 2) based on the mean distance to the herring's main wintering area in Vestfjorden, habitat (continental shelf, continental slope or open ocean) and the age of the herring (young herring: $\leq 6 \mathrm{yr}$, old herring: $>6 \mathrm{yr}$ ). Eleven schools recorded outside these defined sub-areas were omitted from the analysis. Sub-area A is over the continental shelf and slope. The eastern part of sub-area B is over the continental shelf, whereas the northwestern part and sub-area $\mathrm{C}$ is in the open ocean. In 1996 herring schools in sub-area B and $\mathrm{C}$ were studied, and within each sub-area a subset (Fig. 2) of about 100 herring schools was analysed, whereas in 1995 all acoustically recorded schools were analysed.

These 3 school types were excluded to reduce bias: Schools with a mean swimming speed above $2.0 \mathrm{~m} \mathrm{~s}^{-1}$, as the sustained swimming speed of herring of the observed size is below this value (He \& Wardle 1988); school registrations lasting less than 21 pings, due to low data precision during short registration periods (Hafsteinsson \& Misund 1995); and schools where the vessel heading changed by more than $20^{\circ}$ during the recording period, as large changes in vessel direction distorted the apparent school movements.

A computer program (Kvamme 1999) was developed in SAS v.6.03 software to plot the movement of each school and to calculate the mean swimming speed, centre depth and direction of migration (Table 1).

Table 1. School parameters recorded during the surveys in 1995 (7 July to 2 August) and 1996 (9 to 19 July) on the RV 'Johan Hjort' in the Norwegian Sea

\begin{tabular}{|c|c|}
\hline Survey & School parameters ${ }^{\mathrm{a}}$ \\
\hline 1995 & $\begin{array}{l}\text { School distribution } \\
\text { School behaviour category } \\
\text { Direction of migration } \\
\text { Distance to vessel } \\
\text { Swimming speed } \\
\text { Migration speed } \\
\text { School size index } \\
\text { School depth }\end{array}$ \\
\hline $1996^{a}$ & $\begin{array}{l}\text { School behaviour category } \\
\text { Direction of migration } \\
\text { Distance to vessel }\end{array}$ \\
\hline \multicolumn{2}{|c|}{$\begin{array}{l}\text { a In } 1996 \text { only } 2 \text { subsets (Fig. 2) of the school recordings } \\
\text { were analysed, and swimming speed, migration speed, } \\
\text { school size index and school depth was recorded and } \\
\text { estimated by a different method than in 1995, and there- } \\
\text { fore not included in this paper }\end{array}$} \\
\hline
\end{tabular}


a)

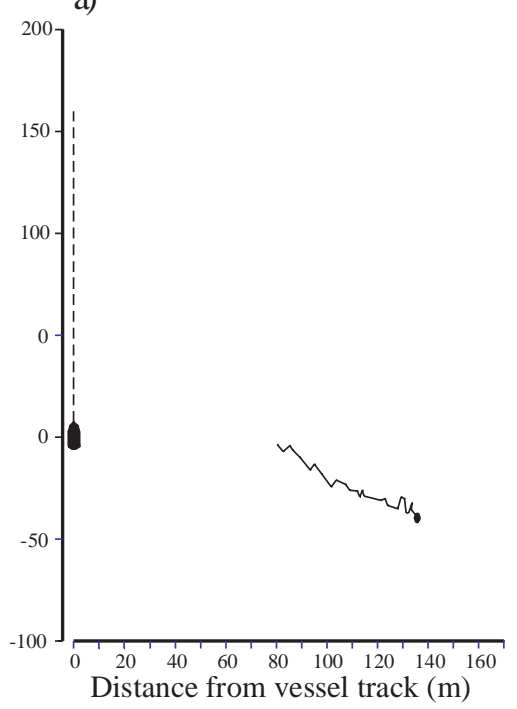

b)

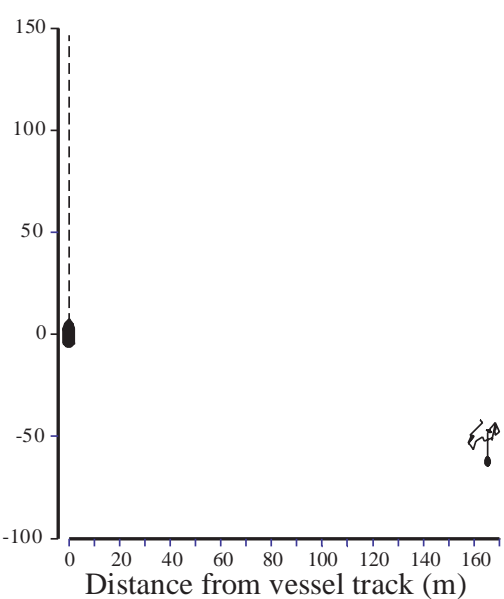

c)

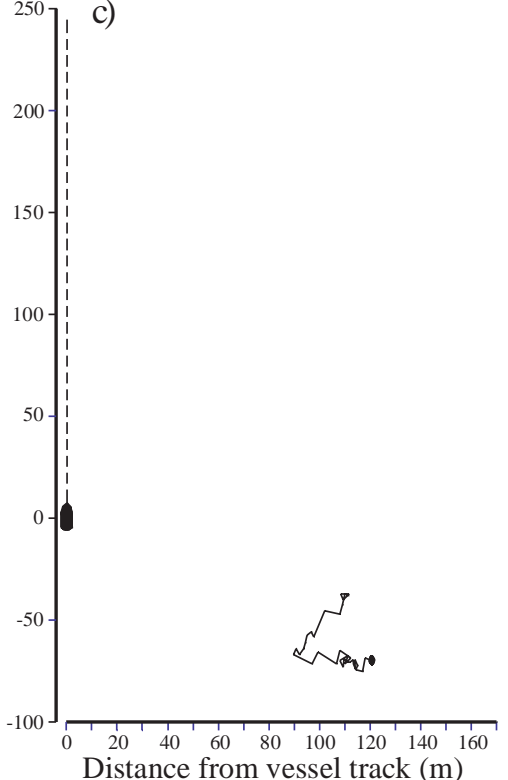

Fig. 4. Examples of different school categories. Vessel movement $(\mathrm{m})$ is parallel to the $y$-axis, and the $x$-axis shows the distance to the vessel track (m). Starting points for both school and vessel are indicated. (a) Migrating school. (b) Non-migrating school. (c) Avoiding school

Analysis of the movements of each school, based on a similar method developed by Hafsteinsson \& Misund (1995), determined the swimming pattern as 'migrating', 'avoiding' or 'non-migrating' (Fig. 4). 'Migrating' schools were defined as moving in straight lines with a clearly defined direction $\left(<45^{\circ}\right.$ change in direction). In longer-lasting registrations ( $>2 \mathrm{~min})$, large changes in bearing $\left(>45^{\circ}\right)$ were accepted if the school had a defined swimming direction when the entire recording was examined. 'Avoiding' schools either: (1) changed their sustained bearing (maintained for a minimum of $10 \mathrm{~s}$ ) by more than $45^{\circ}$ and headed away from the vessel and then maintained this bearing until the vessel passed or the school disappeared from the sonar beam; or (2) changed their sustained bearing by more than $45^{\circ}$ and then approached the vessel track (Misund \& Aglen 1992). 'Non-migrating' schools frequently changed bearing and performed irregular, restricted movements in the course of the observation period.

The direction of migration, $\beta_{\mathrm{M}_{j}}\left(^{\circ}\right.$, direction of movement during the acoustic recording) and migration speed $S_{\mathrm{M}_{j}}\left(\mathrm{~m} \mathrm{~s}^{-1}\right.$, rate of movement in the direction of migration) were calculated from the swimming speed, $S_{i j}\left(\mathrm{~m} \mathrm{~s}^{-1}\right.$ ) and bearing, $\alpha_{i j}\left({ }^{\circ}\right)$ (Hafsteinsson \& Misund 1995). The indices $i$ and $j$ denote ping and school number, respectively. The swimming speed and bearing is estimated by the sonar, based on the change in geographical position of the school's acoustic centre of gravity (the point of maximum density) from ping to ping. For each school, rate of movement in northern
$\left(S_{\mathrm{N}_{i j}}\left[\mathrm{~m} \mathrm{~s}^{-1}\right]\right)$ and eastern $\left(S_{\mathrm{E}_{i j}}\left[\mathrm{~m} \mathrm{~s}^{-1}\right]\right)$ direction was calculated for each ping as:

$$
S_{\mathrm{N}_{i j}}=S_{i j} \times \cos \left(\alpha_{i j}\right)
$$

and

$$
S_{\mathrm{E}_{i j}}=S_{i j} \times \sin \left(\alpha_{i j}\right)
$$

respectively.

The migration speed was calculated as:

$$
S_{\mathrm{M}_{j}}=\sqrt{\left(\frac{1}{N} \sum_{i=1}^{N} S_{\mathrm{N}_{i j}}\right)^{2}+\left(\frac{1}{N} \sum_{i=1}^{N} S_{\mathrm{E}_{i j}}\right)^{2}}=\sqrt{S_{\mathrm{N}_{i j}}{ }^{2}+S_{\mathrm{E}_{j}}{ }^{2}}
$$

while the direction of migration was determined according to:

$$
\beta_{\mathrm{M}_{j}}=\arccos \left(\frac{S_{\mathrm{N}_{j}}}{S_{\mathrm{M}_{j}}}\right)=\arcsin \left(\frac{S_{\mathrm{E}_{j}}}{S_{\mathrm{M}_{j}}}\right)
$$

A rough estimate of each school's horizontal area was calculated from the school's length along the acoustical axis on the sonar screen $(l W, \mathrm{~cm})$, as measured by ruler during the survey. The school length (along the acoustical axis), $L W$, was calculated as:

$$
L W=(l w \times s \times \cos \alpha)-\left(c \times t_{\mathrm{s}} / 2\right)
$$

where $s$ is the ratio between the vessel-school distance and the corresponding distance on the screen ( $s \sim 30 \mathrm{~m} \mathrm{~cm}^{-1}$ with a sonar range of $400 \mathrm{~m}$ ), $\alpha$ the tilt angle $\left(\alpha \approx-7^{\circ}\right), c$ the sound speed $\left(c \approx 1500 \mathrm{~m} \mathrm{~s}^{-1}\right)$ and $t_{\mathrm{s}}$ the pulse length $\left(t_{\mathrm{s}} \approx 2 \times 10^{-3} \mathrm{~s}\right)$. A constant ratio of $3: 2$ between $C W$ (the school's width across the acoustical axis) and $L W$ was assumed (Misund 1990) as there was 

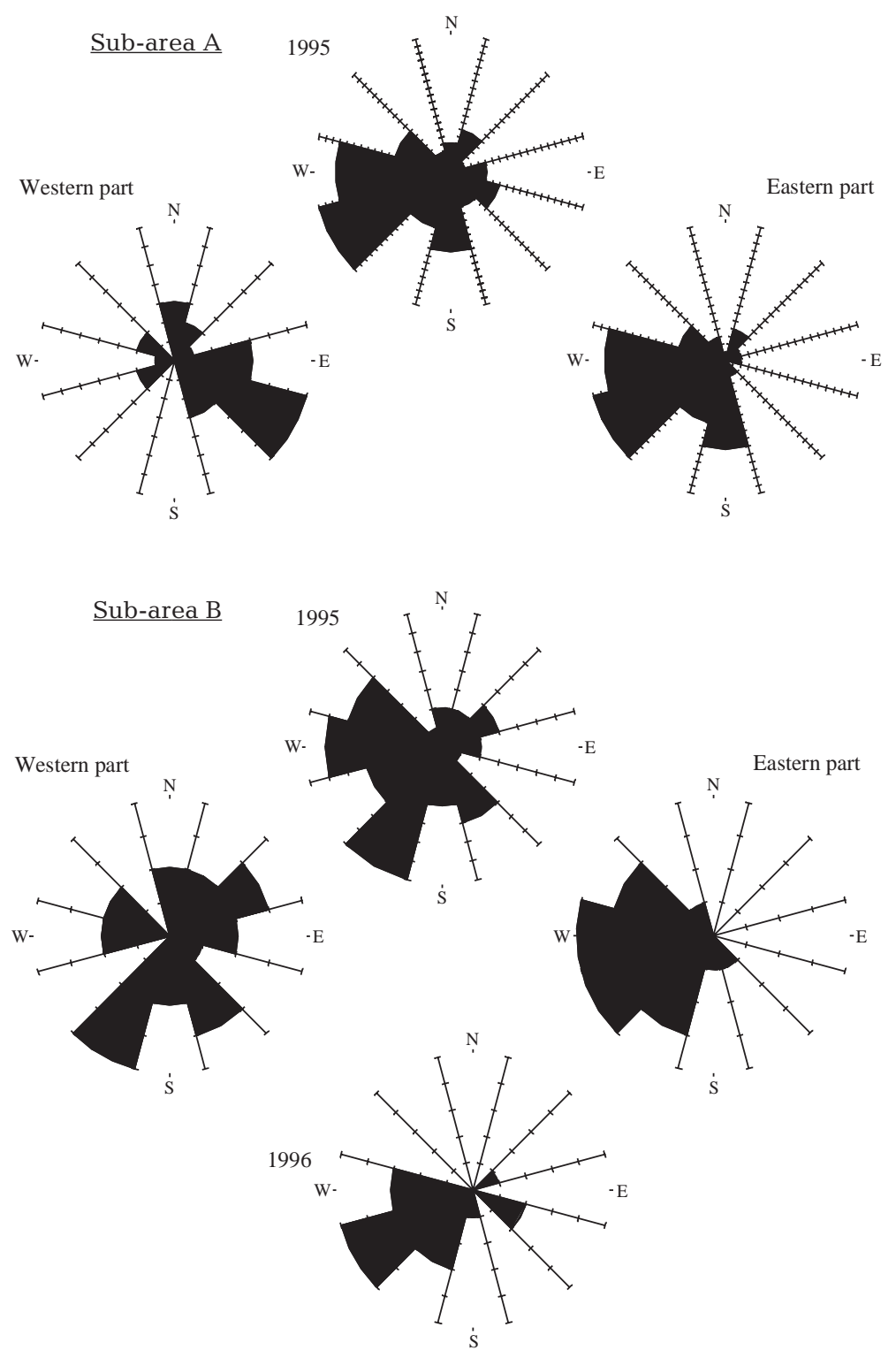

no possibility to measure the width of all schools across the acoustical axis during the survey. An elliptical shape was assumed (Misund 1990), and the school area $\left(\mathrm{m}^{2}\right)$ was calculated as:

$$
A=\frac{\pi(C W \times L W)}{4} \approx \frac{3 \pi(L W)^{2}}{8}
$$

Due to this approximation the school area should be considered a relative index only.

The sonar provided estimated school depth as $\{[$ school-vessel distance $\times$ sin(tilt angle $)]+$ transducer depth\}.

Statistical tests assumed a significance level of $\alpha=0.05$ unless otherwise stated. Most parameters deviated appreciably from the normal distribution and nonparametric tests (Zar 1996) were consequently applied. Differences in the distribution of school categories between sub-areas and years were tested using a chi-square test. The migration directions in the different sub-areas were compared by visual examination of the rose diagrams (Fig. 5). Kruskal-Wallis rank test was used to test for differences in swimming speed, migration speed, school area and depth between sub-areas and school categories. Where significant differences were found, post-hoc comparisons were conducted using a Mann-Whitney $U$-test. Here, the significance level was set to $\alpha^{\prime}=0.05 / C$ (Bonferroni's method, Howell 1987), where $C$ is the number of tests in the post hoc comparison. Single factor analysis of variance (SAS Institute 1990) was carried out to test whether the mean condition factor and the degree of stomach filling varied with different age groups. Differences in condition factor, stomach filling and age of herring between western areas (>500 $\mathrm{m}$ depth) and eastern areas (<500 m depth) were tested by a $t$-test with unequal $\mathrm{n}$.
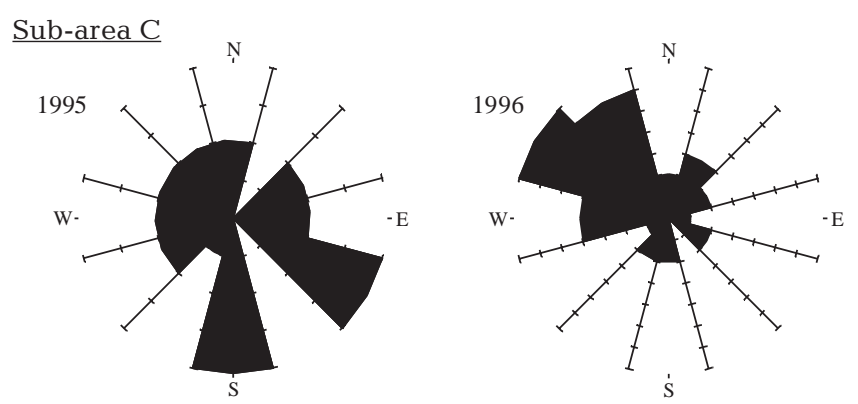

Fig. 5. Clupea harengus. Directions of migration of migrating herring schools in the different sub-areas (Fig. 2) and years (from the 1995 and 1996 survey). The limits between the western and eastern part of sub-area $\mathrm{A}$ and $\mathrm{B}$ are $8^{\circ} \mathrm{E}$ and $12.5^{\circ} \mathrm{E}$, respectively. The class intervals are $30^{\circ}$ and $\mathrm{n}_{\mathrm{A} 95}=94$ (maximum value of axis $=19$ ), $\mathrm{n}_{\text {A95west }}=25(7), \mathrm{n}_{\text {A95east }}=69(17), \mathrm{n}_{\text {B95 }}=40(11), \mathrm{n}_{\text {B95west }}=23(4)$, $\mathrm{n}_{\text {B95east }}=17(4), \mathrm{n}_{\mathrm{B} 96}=15(5), \mathrm{n}_{\mathrm{C} 95}=23(4), \mathrm{n}_{\mathrm{C} 96}=32(7)$

\section{RESULTS}

All recorded schools (sonar, echo sounder) were positioned 0 to $60 \mathrm{~m}$ from the surface (mean centre depth about $20 \mathrm{~m}$ ). The herring were concentrated relatively close to the coast. Sub-area A had the highest and sub-area $\mathrm{C}$ the lowest frequency of school recordings (Table 2). The geographic distribution of the herring schools is given in Fig. 2. The largest observed distance between a school and the innermost part of the wintering area was $930 \mathrm{~km}$.

In 1995 the median length and dominating age were $24 \mathrm{~cm}$ and $3 \mathrm{yr}$ in sub-area A, $27 \mathrm{~cm}$ and $4 \mathrm{yr}$ in sub-area B and $32 \mathrm{~cm}$ and 5 and $12 \mathrm{yr}$ in sub- 
area C (Fig. 6). In sub-area $C$ young and old herring were recorded in the eastern and western parts, respectively. In 19964 -yr-old herring dominated, and the median length was $28 \mathrm{~cm}$ in both sub-areas B and C. Nonmigrating schools dominated in all subareas (Table 2), but the prevalence of the school categories differed among sub-areas and years $\left(\chi^{2}=39.10, p<0.001\right)$. Sub-areas A (1995) and B (1996) differed the most. Sub-area A had a higher prevalence of migrating and avoiding schools and fewer non-migrating schools than the other subareas, whereas sub-area B had a high frequency of non-migrating schools and relatively few migrating and avoiding schools.

The dominant direction of migration among migrating schools was westerly (Fig. 5). In 1995, the mean directions of migration were south-westerly in sub-areas A $\left(231^{\circ}\right)$ and B $\left(229^{\circ}\right)$, and south and southeasterly in sub-area $\mathrm{C}$. The schools did consequently not swim uniformly towards the coast as anticipated. Differences between eastern and western parts were found within sub-areas A and B (Fig. 5). Near the coast, a westerly direction dominated in both sub-areas. In the western part of subarea $\mathrm{A}$ (west of $8^{\circ} \mathrm{E}$ ), easterly migration directions dominated, whereas both westerly and easterly migration directions were found in the western part of sub-area B (west of $12.5^{\circ} \mathrm{E}$ ). The dominant direction of migration near the coast was also westerly in 1996 (Fig. 5). Non-migrating schools had similar directions of movement as migrating schools, but the variation was higher (Kvamme 1999). The direction of migration among avoiding schools differed from both migrating and non-migrating schools and mainly corresponded to the vessel's heading.

The overall mean swimming speed was $0.73 \pm 0.40(\mathrm{SD}) \mathrm{m} \mathrm{s}^{-1}$ and the overall mean migration speed was $0.51 \pm 0.38 \mathrm{~m} \mathrm{~s}^{-1}$. Migrating schools had mean swimming and migration speeds of $0.83 \pm 0.39 \mathrm{~m} \mathrm{~s}^{-1}$ and $0.66 \pm 0.39 \mathrm{~m} \mathrm{~s}^{-1}$, whereas the mean speeds

Fig. 6. Clupea harengus. Length $(\mathrm{cm})$ and age $(\mathrm{yr})$ distribution of herring by percentage for each sub-area (Fig. 2) and year (1995 and 1996 survey). The 1995 data are from the survey report (Anonymous 1996a): $\mathrm{n}_{\mathrm{A} 95}=400, \mathrm{n}_{\mathrm{B} 95}=400, \mathrm{n}_{\mathrm{C} 95}=257$, $\mathrm{n}_{\mathrm{B} 96}=35, \mathrm{n}_{\mathrm{C} 96}=38$
Table 2. Clupea harengus. Relative prevalence of herring school categories (Fig. 4) within the sub-areas (Fig. 2) in 1995 (7 July to 2 August) and 1996 (9 to 19 July) in percentages (absolute numbers in brackets)

\begin{tabular}{|lcllll|}
\hline \multirow{2}{*}{ Survey } & \multirow{2}{*}{ Sub-area } & \multicolumn{3}{c}{ School category } & \multirow{2}{*}{ Total } \\
\cline { 3 - 5 } & & Migrating & Non-migrating & Avoiding & \\
\hline 1995 & A & $35.6(94)$ & $54.9(145)$ & $9.5(25)$ & $38.0(264)$ \\
& B & $24.1(40)$ & $68.1(113)$ & $7.8(13)$ & $23.9(166)$ \\
& C & $31.9(23)$ & $65.3(47)$ & $2.8(2)$ & $10.4(72)$ \\
& All & $31.3(157)$ & $60.7(305)$ & $8.0(40)$ & $72.2(502)$ \\
1996 & B & $13.9(15)$ & $85.2(92)$ & $0.9(1)$ & $15.5(108)$ \\
& C & $37.6(32)$ & $54.1(46)$ & $8.2(7)$ & $12.2(85)$ \\
& All & $24.4(47)$ & $71.5(138)$ & $4.1(8)$ & $27.8(193)$ \\
Total & & $29.4(204)$ & $63.7(443)$ & $6.9(48)$ & $100.0(695)$ \\
\hline
\end{tabular}

1995

Sub-area A
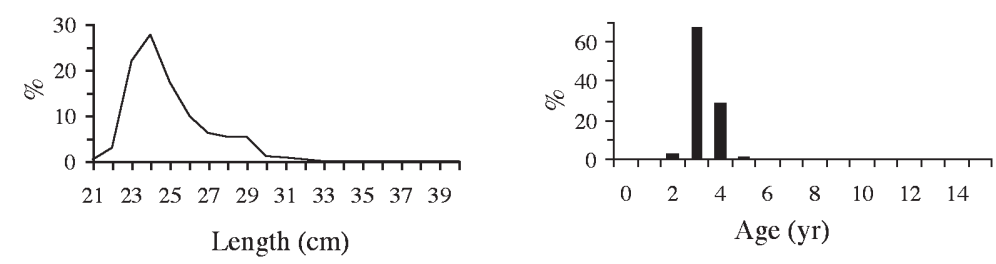

Sub-area B

1995
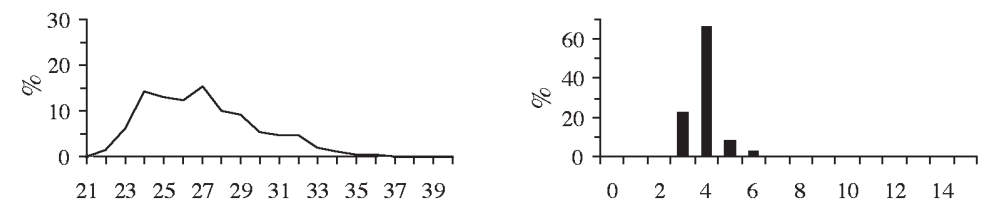

1996
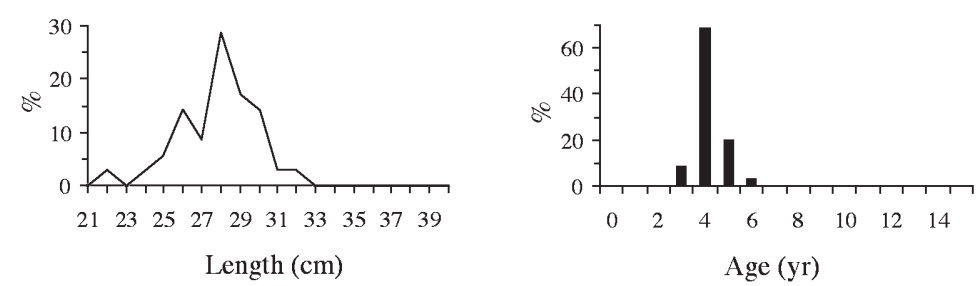

Length $(\mathrm{cm})$

Sub-area C

1995

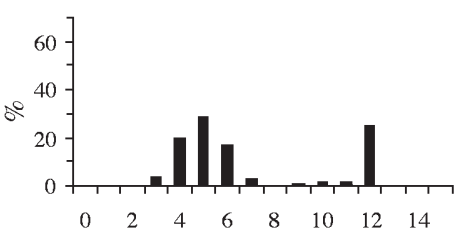

1996
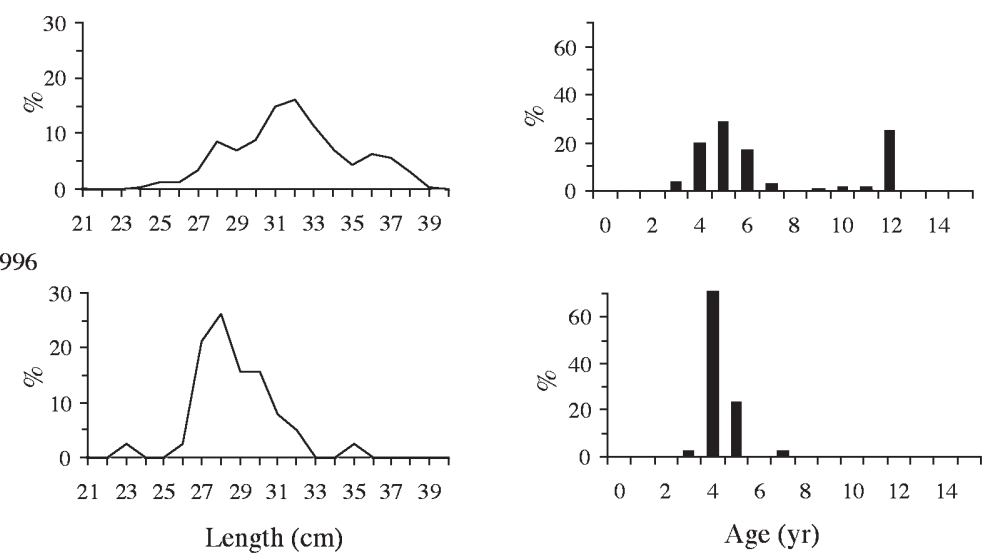
of non-migrating and avoiding schools were respectively lower (swimming speed $=0.64 \pm 0.36 \mathrm{~m} \mathrm{~s}^{-1}$, migration speed $\left.=0.42 \pm 0.34 \mathrm{~m} \mathrm{~s}^{-1}\right)$ and higher $(\mathrm{s}=$ $1.00 \pm 0.50 \mathrm{~m} \mathrm{~s}^{-1}, \mathrm{~m}=0.65 \pm 0.45 \mathrm{~m} \mathrm{~s}^{-1}$ ) (Fig. 7) The combined mean migration speed for migrating and non-migrating schools was $0.50 \mathrm{~m} \mathrm{~s}^{-1}$. In coastal areas (sub-areas A and B) the mean migration speed of migrating schools was $0.65 \mathrm{~m} \mathrm{~s}^{-1}$.

Swimming and migration speeds, school area and centre depth within school categories were compared between sub-areas (Fig. 7). The mean swimming speed was highest in subarea A and lowest in sub-area B. Migrating schools had higher swimming speeds in sub-areas A and C compared to sub-area $B$, and the same trend was observed in migration speed. Sub-area A generally contained larger schools than B and C. School centre depths were not different between subareas (Fig. 7).

Avoiding schools had highest and non-migrating schools lowest mean swimming speeds (Fig. 7). The mean migration speed was lower in nonmigrating schools than in both migrating and avoiding schools. No differences were found between school categories regarding horizontal area and centre depth.

Average age, condition factor and degree of stomach filling per station in July-August 1995 are presented in Fig. 8. The average age was much higher in western areas (4.66 yr) compared to in eastern areas (3.36 yr) $(\mathrm{p}<0.0001, t=10.79$, df $=1787)$. Older herring were found in the northwestern part of the Norwegian Sea, except one observation of old herring east of Shetland and herring had significantly higher condition factor ( $\mathrm{p}<0.05, t=6.47$, df $=2440$ ) in western than eastern areas (Fig. 8). Zooplankton biomass distribution in July-August 1995 in the survey area is shown in Fig. 9. There is a clear tendency of higher zooplankton concentrations in the western areas. The geographical distribution of the ratio between large and small zooplankton shows that the larger zooplankton dominates in 2 areas: in the southwestern corner and a patch near the central Norwegian Sea (Fig. 10). The mean condition factor of herring was different at different ages $(F=3.49, \mathrm{p}<0.0001)$. Fullest stomachs were also found in the western areas, although not statistically significant $(\mathrm{p}=0.41, t=0.82, \mathrm{df}=1925)$. The 10 trawl samples taken in July-August 1996 did not permit a valid comparison between areas.

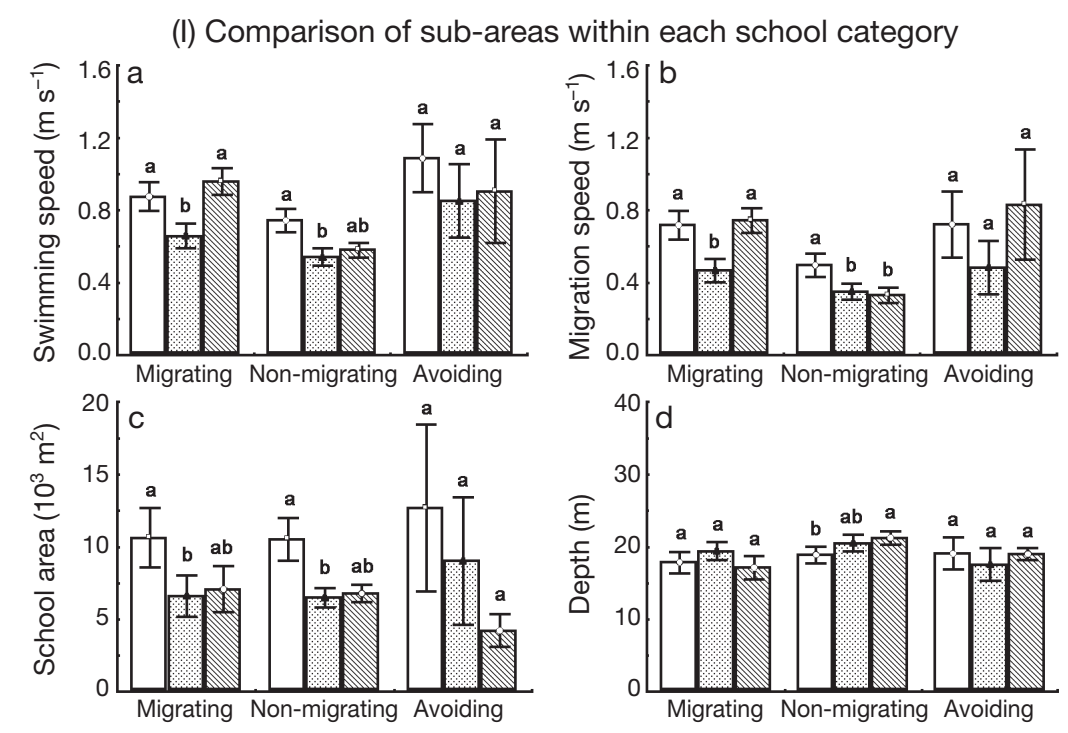

(II) Comparison of school categories within each sub-area

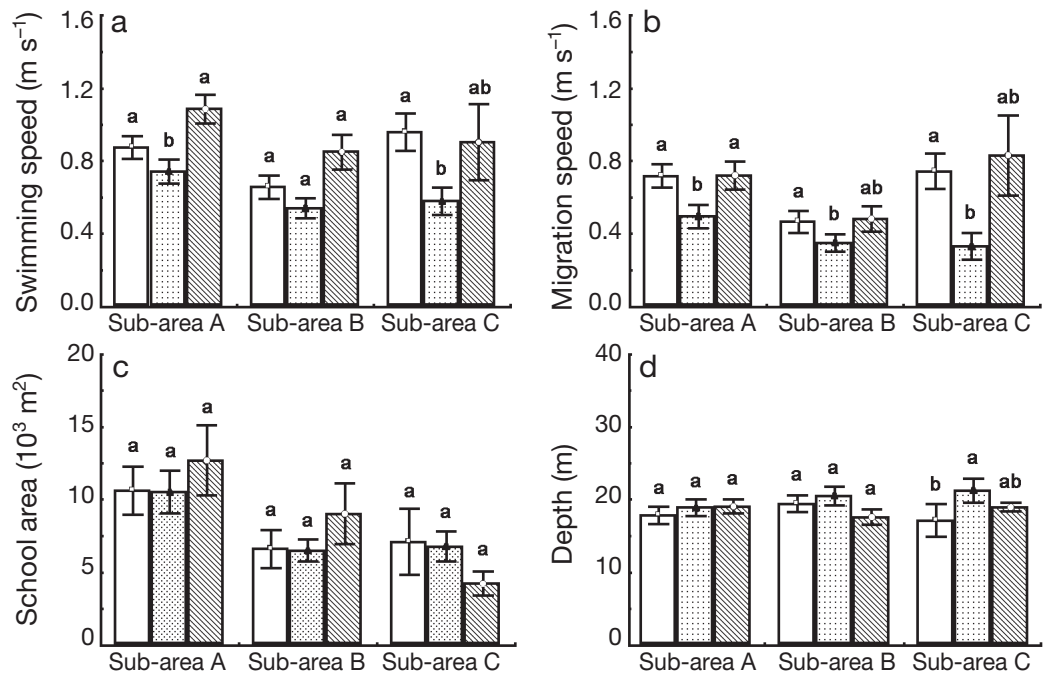

Fig. 7. Clupea harengus. Herring school parameters: comparison of the subareas (Fig. 2) within each school category (Fig. 4) (I) and the school categories within each sub-area (II) for the 1995 survey: (a) swimming speed, $\mathrm{m} \mathrm{s}^{-1}$, (b) migration speed, $\mathrm{m} \mathrm{s}^{-1}$, (c) school area, $10^{3} \mathrm{~m}^{2}$, (d) school depth, $\mathrm{m}$. White columns: sub-area $\mathrm{A} /$ migrating, light grey: sub-area $\mathrm{B} /$ non-migrating, dark grey: sub-area C/avoiding. The whiskers show $\pm 1.96 \times$ standard errors. Different letters indicate differences between the sub-areas/school categories with a significance level of 0.05 (Kruskal-Wallis rank tests and post hoc tests: MannWhitney $U$-tests). Migrating schools: $\mathrm{n}_{\mathrm{A}}=94$ (school area: 89), $\mathrm{n}_{\mathrm{B}}=40(37), \mathrm{n}_{\mathrm{C}}=$ 23 (21); non-migrating: $\mathrm{n}_{\mathrm{A}}=145$ (135), $\mathrm{n}_{\mathrm{B}}=113$ (106), $\mathrm{n}_{\mathrm{C}}=47$ (43); avoiding: $\mathrm{n}_{\mathrm{A}}=25(24), \mathrm{n}_{\mathrm{B}}=13, \mathrm{n}_{\mathrm{C}}=2$ 


\section{DISCUSSION}

\section{School categories}

Movement patterns were used to classify herring schools as migrating, non-migrating or avoiding. Vessel avoidance (Olsen 1971, Hafsteinsson \& Misund 1995) may bias migration studies, but the avoidance was low in our study $(7 \%)$ and avoiding schools excluded when considering migration patterns. The differences between migrating, non-migrating and avoiding schools concerning migration direction, swimming and migration speeds support that the classification criteria were valid. Migrating schools have been reported to react more strongly to vessel noise than feeding schools (Mohr 1969, Misund 1994), and the low prevalence of avoiding schools may reflect high feeding activity. Nonmigrating schools (64\%) frequently changed swimming direction and were presumably foraging, as supported by earlier observations of a variable swimming direction of feeding herring schools (Nøttestad et al. 1996).

From Figs. 2 \& 8 it is clear that school registrations were from the eastern part of the survey area, and the schools detected here mainly consisted of herring less than $6 \mathrm{yr}$ old, although with some herring up to $12 \mathrm{yr}$ old in the western part. Eleven schools from the region west of sub-areas $A, B$ and $C$ were not included in the analysis (Kvamme 1999).

\section{Prey availability}

Feeding conditions varied within the survey area. The biomass of zooplankton increased westwards from the Norwegian coast. The highest biomass was found in the colder water of the East Icelandic current (south western corner of survey region; Hansen \& Østerhus 2000) and near the Arctic front towards Jan Mayen. This is a frequently observed biomass distribution that is seen both in May and July (e.g. Holst et al. 2001). The proportion of larger zooplankton also increased towards the west. However, while the high biomass of zooplankton east of Jan Mayen seemed to be mainly smaller specimens, the zooplankton of the East Icelandic current were both abundant and large. In the larger size fraction, representing the preferred food for herring (Dalpadado et al. 2000), copepodite stages CIV, V and adult Calanus finmarchicus together with $C$. hyperboreus accounted for most of the biomass observed (W. Melle pers. com.). The low biomass of zooplankton on the Norwegian shelf may have been caused by $C$. finmarchicus starting to migrate towards deeper waters for wintering (Slagstad \&
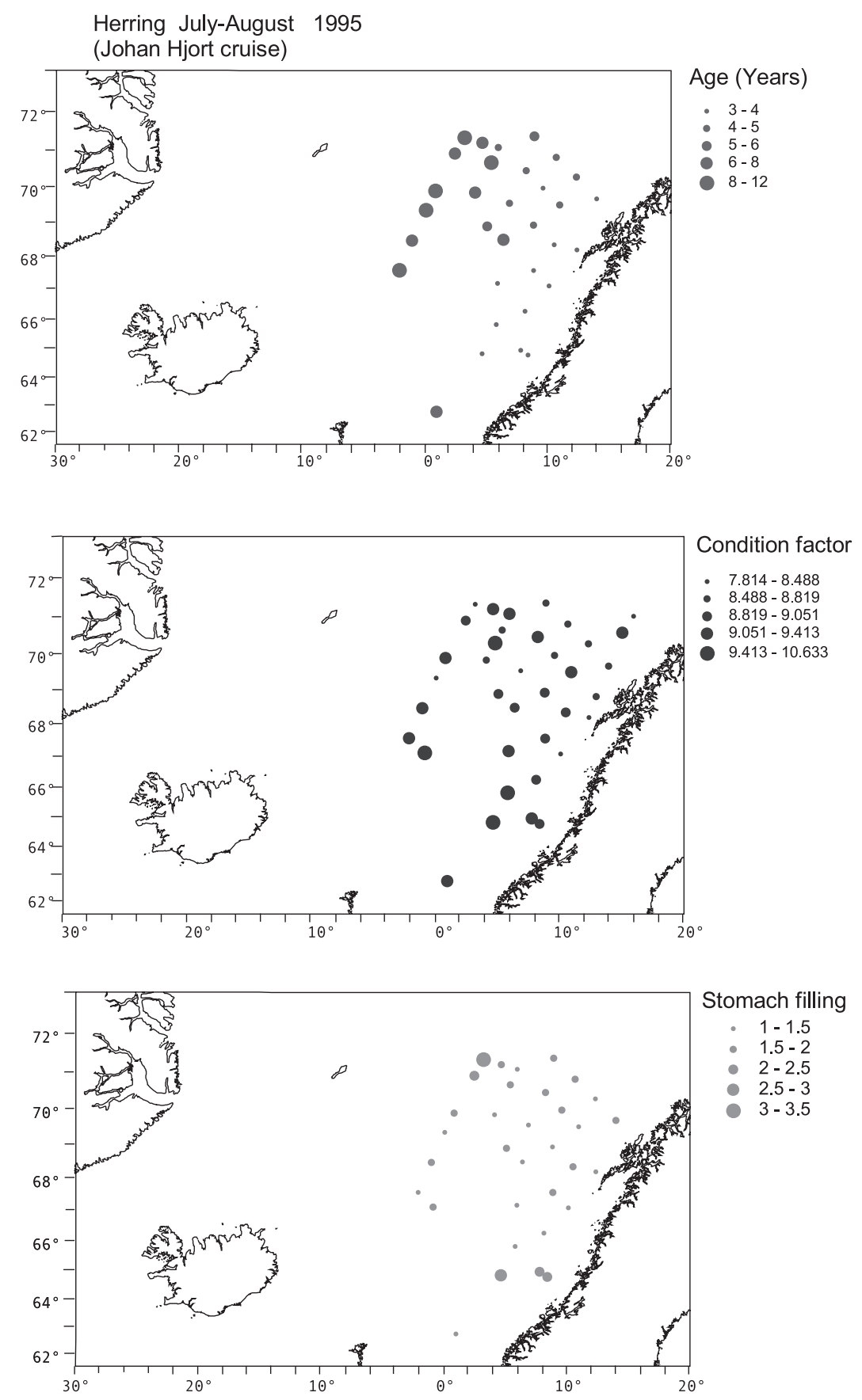

Fig. 8. Clupea harengus. Average age, condition factor, and degree of stomach filling of herring per trawl station in July-August 1995 

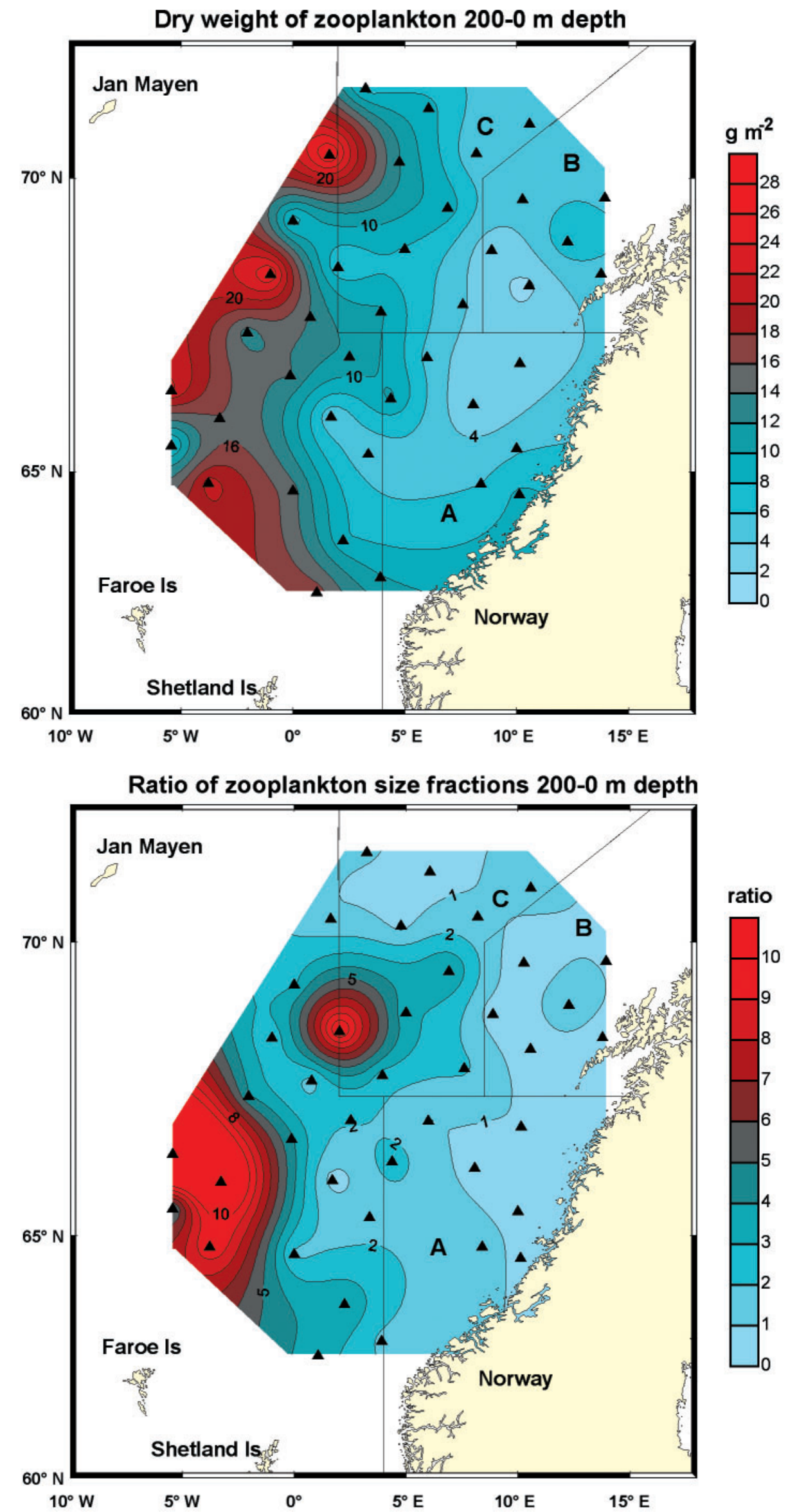

Fig. 9. Zooplankton biomass based on MOCNESS profiles taken during July-August 1995. Contour units are $\mathrm{g}$ dry weight $\mathrm{m}^{-2}$. The zooplankton biomass is total biomass in the upper $200 \mathrm{~m}$. (4) Locations of MOCNESS stations

Fig. 10. Ratio of zooplankton biomass size fractions $(1000 \mu \mathrm{m} / 180 \mu \mathrm{m})$ based on MOCNESS profiles from the upper $200 \mathrm{~m}$ taken during JulyAugust 1995. Contour units are dry weight ratio. ( $\mathbf{\Delta})$ Locations of MOCNESS stations 
Tande 1996). In addition, depletion of prey by predation may have been important. A fish stock confined to a relatively small area may partly deplete its zooplankton prey (Manteufel 1941, Arrhenius 1995, Misund et al. 1998, Cowan et al. 2000), and in 1995 the highest concentrations of herring coincided with the lowest density of zooplankton (Dalpadado et al. 1996). The high biomass of small zooplankton east of Jan Mayen probably represents the production of the first generation of C. finmarchicus of that region, and the high biomass of large zooplankton in the East Icelandic current was probably mainly various life stages of $C$. hyperboreus. Thus, feeding conditions for the herring should be best in the south-western region with high concentrations of large specimens, intermediate in the northwestern region with either high concentrations of small specimens or intermediate concentrations of large specimens, and inferior in the eastern shelf region with low concentrations of small specimens.

Given that herring move towards increasing food concentrations, one should expect herring in sub-areas $\mathrm{A}$ and $\mathrm{B}$ to move westward and herring in the eastern parts of sub-area C to move south or westward. Such migration patterns in fact coincided with observed migration directions, except for the western schools of sub-areas A and C, which seemed to be moving more eastwards. Acoustics and trawl catches showed that old herring still remained in the western areas of high zooplankton biomasses, indicating that the older herring were able to exploit the better feeding areas further away from the wintering site, while the young herring were restricted to prey available closer to the coast.

Herring condition was significantly higher in the western part than at the coast, suggesting that feeding conditions were better offshore. Stomach fullness was also higher in the western part, although not statistically significant. Condition factor gives a historical and accumulated measure of feeding, whereas stomach content only provides an instantaneous measure of food intake that can be influenced by diurnal feeding rhythms and patchy prey distribution.

\section{Migration direction and speed}

At the end of the feeding season herring may meet conflicting demands between moving to areas with uncertain food abundance and predation risk, and migrating to the wintering area at the coast. The dominant direction of migration was not towards the wintering area and migrating schools generally moved westwards in sub-areas A and B. By migrating west herring should have improved the feeding conditions and extended their feeding period. In sub-areas A and
C with high condition factor in several samples, both an eastern and western swimming direction was found, whereas in sub-area B with observed low prey concentrations, more consistent low condition factor and low fish age, most schools moved westwards, away from the wintering area. Schools near the coast within both sub-areas A and B migrated westwards. The westerly migration also in 1996 suggests that a westerly migration is a general way of responding to sub-optimal feeding conditions in coastal areas. No dominant direction of migration was found in sub-area $\mathrm{C}$ and the western part of sub-area $\mathrm{B}$, suggesting that the herring migrated westwards until satisfactory feeding conditions were found. In the western part of sub-area $\mathrm{A}$, an easterly migration even dominated.

No dominant direction of migration was found in sub-area $C$, suggesting satisfactory feeding conditions in this area. Old, long-distance migrating herring may have migrated towards the coastal areas in June-July (Anonymous 1995), and stopped near the frontal area between Atlantic and coastal waters, where feeding conditions were better than at the continental shelf, yet the distance to the wintering area relatively short. A more western herring distribution in August than in July 1995 (Anonymous 1995) suggests that the stay west of frontal areas was not just a short feeding break before continuing eastwards.

Mean swimming and migration speeds for migrating schools were $0.89 \mathrm{~m} \mathrm{~s}^{-1}$ and $0.60 \mathrm{~m} \mathrm{~s}^{-1}$, in accordance with observed swimming speeds for herring (e.g. He \& Wardle 1988, Misund \& Aglen 1992, Hafsteinsson \& Misund 1995). Despite small fish sizes, migration speed in sub-area A was high, suggesting that herring rapidly left areas with low prey availability. Herring have previously been reported to rapidly return from areas with unfavourable conditions (Jakobsson 1969).

\section{Feeding migration strategy of herring}

Young herring have higher migration costs than older herring (Nøttestad et al. 1999), and should thus have different behavioural trade-offs. This may confine young herring primarily to coastal areas. Older herring could afford the costs of migrating out of the area and thus take advantage of higher concentration of food in offshore areas avoiding intra-specific competition in coastal areas (Nøttestad et al. 1999). The results in the present study also supports that young herring trade-off food availability and migration costs differently than older co-specifics.

The best feeding strategy for young herring could be to stay near the coast as long as feeding conditions are satisfactory and to move westwards if conditions 
worsen (see Melle et al. 1994). The westerly migration recorded both in July 1995 and 1996 indicate that this may be a regular migration pattern whenever food is scarce. Food availability in coastal areas is high early in the feeding period (Melle et al. 1994) and in years with a small herring stock (1970s and 1980s) this situation can prevail. It would then be advantageous for both young and old herring to keep the migration costs low by staying near the coast throughout the summer (Nøttestad et al. 1999).

Norwegian spring-spawning herring has a high migratory capacity (Nøttestad et al. 1999). The migration from the feeding area near Spitsbergen and Bjørnøya to the wintering area east of Iceland in 1968 was reported to start at the beginning of September, covering the Bjørnøya to Jan Mayen distance $(\sim 740 \mathrm{~km})$ in $20 \mathrm{~d}$ (Jakobsson 1969), and Røttingen \& Røttingen (1991) estimated that herring moved up to $830 \mathrm{~km}$ in 2 to $3 \mathrm{wk}$ during the spawning migration. In our study, the longest linear distance from a school to the inner parts of the wintering area was $930 \mathrm{~km}$. The combined mean migration speed for migrating and non-migrating schools was $0.50 \mathrm{~m} \mathrm{~s}^{-1}$, or about $43 \mathrm{~km}$ $\mathrm{d}^{-1}$. The herring should then be capable of covering a distance of $930 \mathrm{~km}$ in about $20 \mathrm{~d}$. Herring do not usually enter the wintering area in Vestfjorden until September (Røttingen 1988, 1992), and from an energetic point of view the herring should continue feeding as long as possible before overwintering.

The migration pattern of herring could be controlled by predictive (genetic, learning) and reactive (response to near field, state-space comparisons) mechanisms (Fernö et al. 1998). Genetic factors may operate on a large spatial and temporal scale, learning on an intermediate scale and reactive mechanisms on a small scale. Herring cannot perfectly predict feeding conditions in other areas and are thus not always found in an optimal habitat, but temporal and spatial variations in prey availability, temperature and currents are presumably sufficiently predictable on large scales to provide a selective pressure towards genetically inherent migration directions. Meso-scale environmental variability in the Norwegian Sea, such as changes in the North-Atlantic oscillation (Alheit \& Hagen 1997) and inter-annual variation in prey distribution (Holst et al. 1998, Corten 2000) creates, however, a need for flexible knowledge, provided by learning of favourable sites that may vary from generation to generation. Different year classes may in addition to different migration costs have different experiences, and young herring from the strong 1959 year-class had a totally different migration pattern from 1962 to 1965 than old herring (Fig.1b), suggesting an effect by learning. The environment also varies spatially and temporally on a small scale, e.g. in terms of patchy prey distribution and depletion. Reactive mechanisms tuning the predictive orientation mechanisms (genetic and learning) to unpredictable local variation may therefore be crucial, and a combination of these mechanisms could enable herring to orient in a predictable but stochastically varying environment (Fernö et al. 1998). Huse \& Giske (1998) described the spatial movements of fish by an individual-based model combining reactive (by an artificial neural network) and predictive (by adapting the weights of the neural network by a genetic algorithm) orientation mechanisms.

Sub-optimal feeding conditions may trigger a largescale western migration after spawning, on the basis of a prediction of high concentrations of food (Fernö et al. 1998). In our study, young herring may have used the same predictive orientation mechanism in July when swimming westwards. This indicates that westwards swimming can also be released late in the feeding season. Older herring, mostly found in the western areas, may have chosen to feed in open ocean on their way to the wintering area either by using only reactive orientation mechanisms and feeding whenever good feeding conditions were met, or by using a combination of reactive and predictive mechanisms where previous experience caused them to avoid low prey densities in coastal areas in late summer by feeding west of the continental slope. A possible parallel is observed in migrating birds. During the autumn migration, many birds take a feeding break shortly before crossing ocean areas (Alerstam 1978, 1990). Prey densities may, however, be low in coastal areas, and observations suggest that older birds take breaks before reaching these areas, based on previous experience (Alerstam 1978).

Corten (2000) suggested an adaptation of herring migration to changes in timing of the Calanus finmarchicus seasonal cycle by a collective memory. A conservative migration and feeding strategy may have kept herring waiting in a sub-optimal feeding area for an improvement in coastal feeding conditions (see Corten 2000). In some cases a conservative strategy, i.e. waiting for a new plankton bloom without leaving the area prematurely, may be a proper feeding strategy, but there must be a time limit. In our study, when feeding conditions at the coast did not improve, the tendency of herring to leave the area seemed to increase.

Seen together with the conservative choice of wintering area observed the last decade (Fernö et al. 1998) there is an interesting possibility that the older herring's avoidance of coastal areas in late summer, may be explained by a collective memory in the population (Fernö et al. 1998, Corten 2000). A trade-off between distance to a memorized wintering area and better feeding opportunities in another area may determine 
the migration pattern in late summer. If the migration costs by swimming to the former wintering area in late summer become too high, herring may well establish a new wintering area as documented in the 1950s and 1960s.

Acknowledgements. We would like to thank Olav Dragesund and Arne Johannessen for valuable inputs and Svein Løkkeborg for remarks on the manuscript. Anne-Britt Skaar Tysseland prepared most of the figures.

\section{LITERATURE CITED}

Alerstam T (1978) Reoriented bird migration in coastal areas: dispersal to suitable resting grounds? Oikos 30:405-408

Alerstam T (1990) Bird migration. Cambridge University Press, Cambridge

Alheit J, Hagen E (1997) Long-term climate forcing of European herring and sardine populations. Fish Oceanogr 6: $130-139$

Anonymous (1995) Report on surveys of the distribution and migrations of the Norwegian spring spawning herring and the environment of the Norwegian Sea and adjacent waters during the spring and summer of 1995. Reykjavik 11-13 September 1995. Marine Research Institute, Reykjavik

Anonymous (1996a) Interne toktrapporter no 3-1996. Preliminary cruise report, R/V 'Johan Hjort', 7 July-2 August, cruise no. 7 1995. Interne Notat no. 7 1996. Institute of Marine Research, Bergen

Anonymous (1996b) Report on surveys of the distribution and migrations of the Norwegian spring spawning herring and the environment of the Norwegian Sea and adjacent waters in late winter, spring and summer of 1996. Reykjavik 24-26 September 1996. Marine Research Institute, Reykjavik

Arrhenius F (1995) Feeding ecology of Baltic Sea herring (Clupea harengus L.) field and model studies of a dominant zooplanktivor. $\mathrm{PhD}$ thesis, Stockholm University

Corten A (1993) Learning processes in herring migrations. ICES Counc Meet Pap 1993/H:18

Corten A (2000) A possible adaptation of herring feeding migrations to a change in timing of the Calanus finmarchicus season in the eastern North Sea. ICES J Mar Sci $57: 1261-1270$

Cowan JH Jr, Rose KA, DeVries DR (2000) Is densitydependent growth in young-of-the-year fishes a question of critical weight? Rev Fish Biol Fish 10(1):61-89

Dalpadado P, Melle W, Ellertsen B, Dommasnes A (1996) Food and feeding conditions of herring Clupea harengus in the Norwegian Sea. ICES Counc Meet Pap 1996/L:20

Dalpadado P, Ellertsen B, Melle W, Dommasnes A (2000) Food and feeding conditions of Norwegian spring-spawning herring (Clupea harengus) through its feeding migrations. ICES J Mar Sci 57:843-857

Dragesund O, Hamre J, Ulltang Ø (1980) Biology and population dynamics of the Norwegian spring-spawning herring. Rapp P-V Réun Cons Int Explor Mer 177:43-71

Dragesund O, Johannessen A, Ulltang $\varnothing$ (1997) Variation in migration and abundance of Norwegian spring spawning herring (Clupea harengus L.). Sarsia 82:97-105

Fernö A, Pitcher TJ, Melle W, Nøttestad L, Mackinson S, Hollingworth C, Misund OA (1998) The challenge of the herring in the Norwegian Sea: making optimal collective spatial decisions. Sarsia 83:149-167
Fridriksson A, Aasen O (1950) The Norwegian-Icelandic herring tagging experiments. Rep. no. 1. Fisk.dir Skr (Ser Havunders) 9(11):1-43

Hafsteinsson MT, Misund OA (1995) Recording the migration behaviour of fish schools by multi-beam sonar during conventional acoustic surveys. ICES J Mar Sci 52:915-924

Hansen B, Østerhus S (2000) North Atlantic-North Seas exchanges. Prog Oceanogr 45:109-208

Harden Jones FR (1968) Fish migration. Edward Arnold, London

He P, Wardle CS (1988) Endurance at intermediate swimming speeds of Atlantic mackerel, Scomber scombrus L., herring, Clupea harengus L., and saithe, Pollachius virens L. J Fish Biol 33:255-266

Holst JC, Arrhenius F, Hammer C, Håkansson N, Jacobsen JA, Krysov A, Melle W, Vilhjálmsson H (1998) Report on surveys of the distribution, abundance and migrations of the Norwegian spring-spawning herring, other pelagic fish and the environment of the Norwegian Sea and adjacent waters in late winter, spring and summer of 1998. ICES Counc Meet Pap 1998/D:3

Holst JC, Couperus B, Hammer C, Jacobsen JA, Krysov A, Melle W, Tangen Ø, Vilhjálmsson H (2001) Report on surveys of the distribution, abundance and migrations of the Norwegian spring-spawning herring, other pelagic fish and the environment of the Norwegian Sea and adjacent waters in late winter, spring and summer of 2001. ICES Counc Meet Pap 2001/D:07

Howell DC (1987) Statistical methods for psychology. Duxbury Press, Boston

Huse G, Giske J (1998) Ecology in Mare Pentium: an individual-based spatio-temporal model for fish with adapted behaviour. Fish Res 37:163-178

Jakobsson J (1969) On herring migrations in relation to changes in sea temperature. Joekull 19:134-145

Jakobsson J, Østvedt OJ (1996) A preliminary review of the joint investigations on the distribution of herring in the Norwegian and Icelandic seas 1950-1970. ICES Counc Meet Pap 1996/H:14

Johannessen SØ (1992) Operator manual SIMRAD SR 240 sonar (software version 5.0x). SIMRAD, Kongsberg

Knudsen HP (1990) The Bergen Echo Integrator: an introduction. J Cons 47:167-174

Kvamme C (1999) Multiskala sonarstudium av norsk vårgytende sild (Clupea harengus L.): vandringsmønster i slutten av beiteperioden. Masters thesis, University of Bergen

Manteufel BP (1941) The plankton and the herring in the Barents Sea. Transactions of the Knipovich Polar Scientific Institute of Sea-Fisheries and Oceanography (Murmansk, USSR) 7:125-218 (in Russian with English summary)

Melle W, Røttingen I, Skjoldal HR (1994) Feeding and migration of Norwegian spring spawning herring in the Norwegian Sea. ICES Counc Meet Pap 1994/R:9

Misund OA (1990) Sonar observations of schooling herring: school dimensions, swimming behaviour, and avoidance of vessel and purse seine. Rapp P-V Réun Cons Int Explor Mer 189:135-146

Misund OA (1993) Dynamics of moving masses: variability in packing density, shape and size among herring, sprat and saithe schools. ICES J Mar Sci 50:145-160

Misund OA (1994) Swimming behaviour of fish schools in connection with capture by purse seine and pelagic trawl. In: Fernö A, Olsen S (eds) Marine fish behaviour in capture and abundance estimation. Fishing News Books, Blackwell Science, Oxford, p 84-106 
Misund OA, Aglen A (1992) Swimming behaviour of fish schools in the North Sea during acoustic surveying and pelagic trawl sampling. ICES J Mar Sci 49:325-334

Misund OA, Melle W, Fernö A (1997) Migration behaviour of Norwegian spring spawning herring when entering the cold front in the Norwegian Sea. Sarsia 82:107-112

Misund OA, Vilhjálmsson H, Jákupsstovu SH, Røttingen I and 7 others (1998) Distribution, migration and abundance of Norwegian spring spawning herring in relation to the temperature and zooplankton biomass in the Norwegian Sea as recorded by coordinated surveys in spring and summer 1996. Sarsia 83:117-127

Mohr H (1969) Observations on the Atlanto-Scandian herring with respect to schooling and reactions to fishing gear. FAO Fish Rep 62:567-577

Nøttestad L, Aksland M, Beltestad A, Fernö A, Johannessen A, Misund OA (1996) Schooling dynamics of Norwegian spring spawning herring (Clupea harengus L.) in a coastal spawning area. Sarsia 80:277-284

Nøttestad L, Giske J, Holst JC, Huse G (1999) A length-based hypothesis to explain feeding migrations in pelagic fish. Can J Fish Aquat Sci 56:26-34

Olsen K (1971) Influence of vessel noise on behaviour of herring. In: Kristjonsson $\mathrm{H}$ (ed) Modern fishing gear of the world: 3: Fish finding, purse seining, aimed trawling. Fishing News Books, London, p 291-294

Editorial responsibility: Otto Kinne (Editor),

Oldendorf/Luhe, Germany
Østvedt OJ (1965) The migration of Norwegian herring to Icelandic waters and the environmental conditions in May-June, 1961-1964. Fisk.dir Skr (Ser HavUnders) 13(8): 29-47

Pavshtiks EA (1959) Seasonal changes in plankton and feeding migrations of herring. Spec Sci Rep US Fish Wildl Serv 327:104-139

Røttingen I (1988) Distribution and migration of the 1983 year class of Norwegian spring spawning herring in the period July 1987-August 1988. ICES Counc Meet Pap 1988/H:41

Røttingen I (1992) Recent migration routes of Norwegian spring spawning herring. ICES Counc Meet Pap 1992/H: 18

Røttingen I, Røttingen J (1991) Swimming speed of spent Norwegian spring spawning herring. ICES Counc Meet Pap 1991/H:9

SAS Institute (1990) SAS/STAT user's guide, Version 6, 4th edn, Vol 2. SAS Institute, Cary, NC

Slagstad D, Tande KS (1996) The importance of seasonal vertical migration in across shelf transport of Calanus finmarchicus. Ophelia 44:189-205

Slotte A (1999) Differential utilization of energy during wintering and spawning migration in Norwegian springspawning herring. J Fish Biol 54:338-355

Zar JH (1996) Biostatistical analysis. Prentice Hall, Upper Saddle River, NJ

Submitted: June 19, 2001; Accepted: August 19, 2002

Proofs received from author(s): January 6, 2003 